\title{
Comparison of the Short-Term Efficacy of Physical Therapy in Subacromial Impingement Syndrome Patients with Stage I and II Magnetic Resonance Imaging Findings
}

\author{
Evre I ile II Manyetik Rezonans Görüntüleme Bulgularına Sahip Subakromiyal Sıkışma
} Sendromlu Hastalar Arasında Fizik Tedavinin Kısa Dönemli Etkinliğinin Karşılaştırılması

\author{
Aral HAKGÜDER, ${ }^{1}$ Nurettin TAŞTEKİN, ${ }^{1}$ Murat BİRTANE, ${ }^{1}$ Kaan UZUNCA, ${ }^{1}$ Coşkun $Z_{A T E R I ̇}{ }^{2}$ Necdet SÜT ${ }^{3}$ \\ ${ }^{1}$ Departments of Physical Medicine and Rehabilitation, Medical Faculty of Trakya University, Edirne, Turkey; \\ ${ }^{2}$ Departments of Physical Medicine and Rehabilitation, Medical Faculty of Çanakkale Onsekiz Mart University, Çanakkale, Turkey; \\ ${ }^{3}$ Departments of Biostatistical, Medical Faculty of Trakya University, Edirne, Turkey
}

Objectives: In this study, we compared the efficacy of a combined physical therapy program between stage I and II subacromial impingement syndrome patients.

Patients and methods: Forty-three patients with subacromial impingement syndrome assessed as stage I and II according to the magnetic resonance imaging (MRI) findings were included in the study. Constant's and University of California Los Angeles Shoulder Scales were used to evaluate pain and function. Pain levels at rest, during motion and while asleep were also scored by visual analog scale before treatment, after treatment and at one month after treatment. Improvements within and between the groups were assessed. A physical therapy program consisting of ultrasound, superficial heat therapy and transcutaneous electrical nerve stimulation modalities combined with an appropriate exercise program was applied to both groups during half monthly sessions.

Results: The between-groups comparisons performed after treatment and during follow-up revealed no significant difference in terms of the outcome measures assessed.

Conclusion: Stage II patients responded to the physical therapy program as well as patients with stage I MRI findings.

Key words: Physical therapy; shoulder pain; subacromial impingement syndrome; supraspinatus rupture.

Subacromial impingement syndrome (SIS) is the most common disorder of the shoulder causing pain and deterioration of function. The main mechanism is subacromial impingement of rotator cuff tendons
Amaç: Bu çalışmada evre I ve II kısmi subakromiyal sıkışma sendromlu hastalar arasında kombine fizik tedavi programının etkinliği karşılaştırıldı.

Hastalar ve yöntemler: Manyetik rezonans görüntüleme (MRG) bulgularına göre evre I ve II olarak değerlendirilen subakromiyal sıkışma sendromlu 43 hasta çalışmaya dahil edildi. Ağrı ve fonksiyonel durumu değerlendirmek için Constant ve Kaliforniya Los Angeles Üniversitesi Omuz Skalası kullanıldı. Tedavi öncesinde, tedavi sonrasında ve tedaviden 1 ay sonra istirahat, hareket ve uyku esnasındaki ağrı seviyeleri görsel analog skala ile puanlandı. İki grup arasında ve grupların kendi içindeki iyileşmeler değerlendirildi. On beş günlük seanslarda uygun egzersiz programı ile birlikte ultrason, yüzeyel sıcak tedavisi ve transkütanöz elektriksel sinir stimülasyonu yöntemlerini içeren fizik tedavi programı her iki gruba da uygulandı.

Bulgular: Gruplar arası karşılaştırma tedavi sonrası ve takipler süresindeki değerlendirme ölçütleri karşılaştırıldığında anlamlı bir fark ile karşılaşılmadı.

Sonuç: Evre II hastalar fizik tedavi programına evre I MRG bulgularına sahip hastalar kadar iyi yanıt verdi.

Anahtar sözcükler: Fizik tedavi; omuz ağrısı; subakromiyal sıkışma sendromu; supraspinatus yırtığı.

(mainly supraspinatus), long head of biceps tendon and subacromial bursa between the humeral head and coracoacromial arch caused by repetitive overhead activities of the arm. Neer ${ }^{[1,2]}$ described the main 
features of SIS first in 1972. He has classified three stages of SIS. In stage I, there is edema and hemorrhage; in stage II, cuff fibrosis, thickening and partial cuff tearing occur; in stage III, full thickness tendon tears, bony changes and tendon rupture are specific findings. SIS presents in many forms including bursitis and degenerative tendinitis and can lead to partial or fullthickness ruptures of the supraspinatus muscle and tendon. The first treatment choice in partial ruptures is widely accepted as being conservative, and even in total ruptures this is so, despite some controversial beliefs. ${ }^{[3]}$

Three current accepted approaches to the treatment of SIS include conservative management, arthroscopic surgery and open surgical interventions. All of these therapeutic modalities have been found to be effective, even though there are arguments in the medical literature $^{[4,5]}$ about their success rates. Conservative approaches are preferred in therapy for stage I and II patients. The overall clinic may also be observed to be asymptomatic in patients with complete and partial ruptures. The literature indicated that most patients who have impingement syndrome eventually recover with non-operative interventions. The general therapy approach includes conservative interventions for stage I and II. In stage III, a long-term conservative approach is needed before a probable surgical procedure. ${ }^{[6,7]}$

Even in advanced stages, conservative therapy can be beneficial precluding surgery. Based on the effectiveness of noninvasive therapies, many investigators recommend a period of conservative management for at least 6-12 months. ${ }^{[8-12]}$ Conservative therapy could be a valuable option in patients with SIS. Physiotherapy (physical therapy modalities and strength-stretching exercises), corticosteroid injections into the glenohumeral joint and nonsteroid anti inflammatory agents have been listed as conservative therapy approaches in the treatment of SIS. Physiotherapy does not have a direct effect on pathology as in surgery such as repairing the rupture or debridement. However, some physical therapy agents, such as ultrasound and low-level laser, ameliorate injured tissue via regulated circulation and induced collagen synthesis. ${ }^{[13,14]}$ Other main aims of physiotherapy are to reduce pain and disability by improving the biomechanics and movement patterns of the shoulder complex. In clinical practice, patients with SIS receive a combination of physiotherapy interventions in order to effectively address the modifiable factors contributing to pain and dysfunction. ${ }^{[10-12]}$
Studies that assessed the efficacy of conservative treatment on SIS had heterogeneous grouping in terms of pathologic stages. They frequently ignored the major pathologic differences during the allocation of the SIS groups investigated. However, some of the stage II patients are known to have further pathologic changes such as partial supraspinatus tendon rupture when compared with stage I SIS with intact tendons. Response to conservative therapy may be different between two stages, probably being worse in patients in stage II according to our hypothesis, as tendon continuity deteriorates in this stage. Since early surgery and smaller rupture size are good predictors for the outcome of SIS surgery, the question of whether the response to conservative treatment is different between two stages is important. ${ }^{[15,16]}$ Hence, patients who have a partial rupture and a poor response to conservative treatment could be treated surgically at an earlier time.

To the best of our knowledge, no study has compared the efficacy of conservative treatment between these two stages in literature. Therefore we aimed to evaluate and compare the efficacy of a combined physical therapy and exercise program in SIS patients with and without increased signal intensity in the tendon.

\section{PATIENTS AND METHODS}

\section{Patients}

Forty-three patients who were diagnosed with SIS by history, clinical signs (Neer test, Hawkins-Kennedy test), subacromial injection test and magnetic resonance imaging (MRI) findings were included in the study program. The pathologic changes in RC tendons were classified according to the Zlatkin et al., ${ }^{[17]}$ MRI Stages of SIS by an experienced radiologist with stage 0 representing tendon morphology and signal intensity normal; stage I representing increased signal intensity in the tendon without any thinning irregularity or discontinuity; stage II representing increased signal intensity with irregularity and thinning tendon; and stage III representing complete disruption of the supraspinatus tendon.

Magnetic resonance imaging findings revealed subacromial impingement syndrome stage I and II. Regarding the MRI findings, patients were allocated into two groups according to whether partial supraspinatus rupture was present (group 1; 13 females, 4 males; mean age $58.3 \pm 7.3$ years) or not present (group 2; 18 females, 8 males; mean age 
$49.3 \pm 7.5$ years). Exclusion criteria were the following: Zlatkin stage III with full thickness tears, positivity of drop arm test, shoulder instability, frozen shoulder, calcifying tendinitis, acute bursitis and steroid injection history to shoulder within three months, concomitant cervical radiculopathy, degenerative arthritis of the glenohumeral joint, shoulder instability and posttraumatic disorders.

Patients who were referred from a general physical medicine and rehabilitation practice outpatient clinic to our "special shoulder outpatient clinic" due to shoulder pain were assessed. Those who were diagnosed as having SIS according to physical examination and MRI findings were eligible for the study. Patient selection and group constitutions can be seen in Figure 1.

For each participant, a trained physician completed a detailed questionnaire about his/her demographic factors and medical history. The physician who completed the interview also performed a thorough physical examination. For participants who were able to tolerate the exercise, a detailed physical therapy program was initiated under the supervision of another specialist. All patients were informed about the study procedures.

\section{Pain and functional evaluation}

The University of California Los Angeles (UCLA) and Constant Shoulder Score Scale were used to evaluate pain and function. ${ }^{[18,19]}$ The UCLA shoulder score is a 35 point scale consisting of 10 points for pain, 10 points for function, and 5 points each for motion, strength and patient satisfaction. A higher score indicates increased shoulder function. Although originally designed to assess outcome after shoulder arthroplasty, it is often used in the shoulder literature to assess results after rotator cuff repair. The Constant Score ${ }^{[20]}$ is the functional score currently recommended by the European Society for Surgery of the Shoulder and the Elbow and by the British Elbow and Shoulder Society. The score reflects shoulder function with accuracy, reliability, and reproducibility. ${ }^{[20-23]}$ It is easy to use with a low intraobserver and interobserver error. ${ }^{[22]}$ The score combines subjective and objective measures to produce a 100 point score. The four parameters used are Activities of Daily Living (ADLs), range of motion (ROM), pain, and strength. These are scored out of a maximum of 20,40, 15, and 25 points, respectively, and the scores are combined to give the overall total. The maximum score is 100 points with lower values indicating progressive shoulder limitation. For additional evaluation of pain, visual analog scale (VAS) was assessed for pain in rest, motion and sleep by patients' marking on a scale ranging from 0 to 10 . These parameters were recorded before (visit-1), after treatment (visit-2) and one month after end of treatment (visit-3). The patients were instructed to stop paracetamol intake three days before the visits.

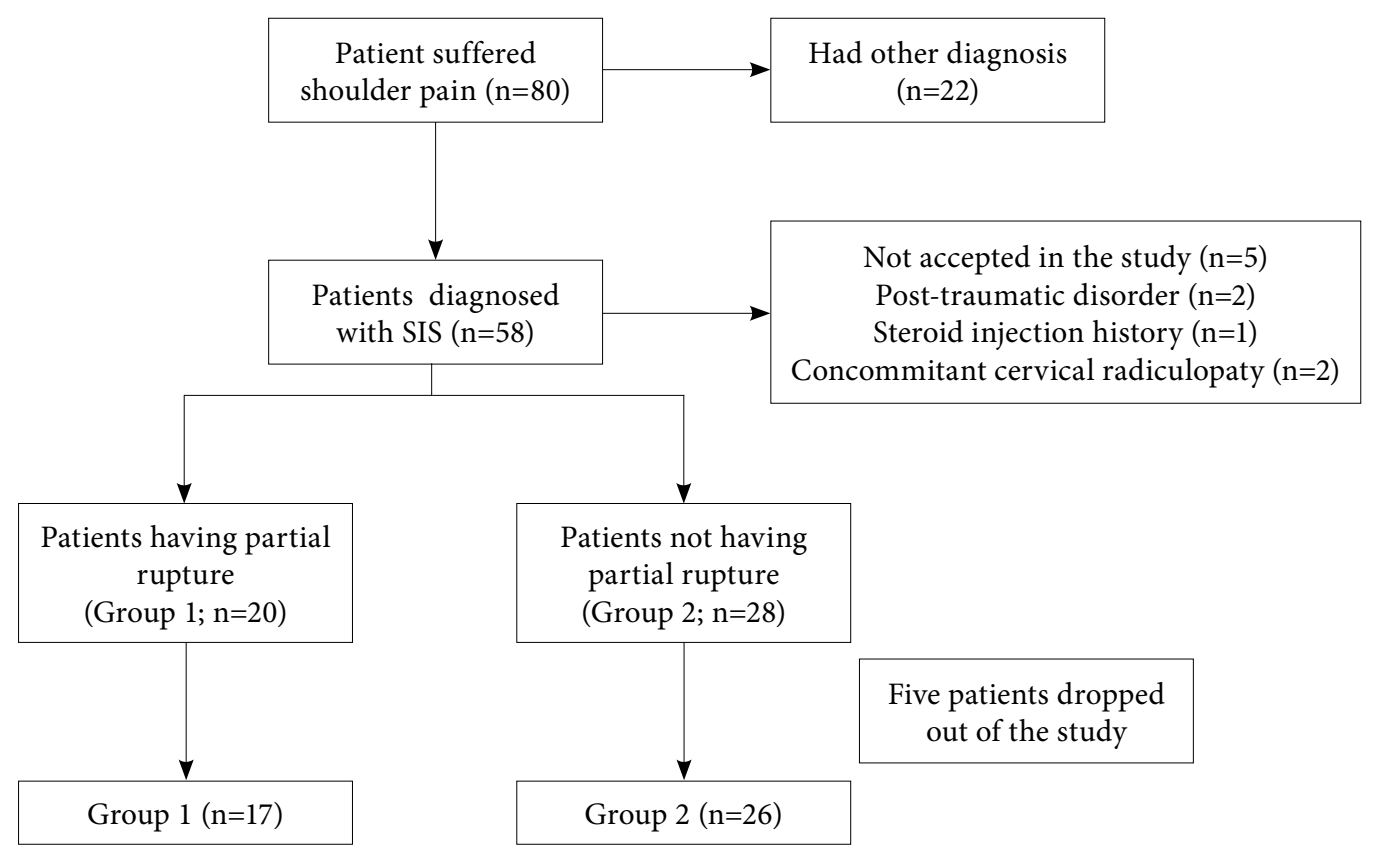

Figure 1. Flow diagram of patient follow-up. 


\section{Treatment program}

The physical therapy program consisted of ultrasound, superficial heat therapy, and transcutaneous electrical nerve stimulation (TENS) modalities combined with Codman's pendulum exercises, assistive ROM, posterior capsular stretching, wall isometric and elastic Thera-Band strengthening exercises for rotator cuff muscles. This program was applied to both groups during 15 daily sessions. Each session lasted one hour. All physical therapy programs were performed in our day care rehabilitation.

- The standard TENS (Carci Ind., Transmed IV, Ref: 4305, Brasil) therapy consisted of the placement of four medium-sized $(2.5 \mathrm{~cm})$ cutaneous electrode pads placed around and on the shoulder region for 20 minutes with $100 \mathrm{~Hz}$ frequency, $0.2 \mathrm{~ms}$ pulse duration and tolerable intensity. The intensity of the electrical stimulation was adjusted to the maximum tolerated amplitude without producing muscle contractions.

- Sonopuls 434 (Enraf, Holland) was used with a frequency of $1.5 \mathrm{MHz}$, and an intensity of $1.5 \mathrm{~W} / \mathrm{cm}^{2}$. The transducer head had an area of $4 \mathrm{~cm}^{2}$. The US was applied with a slow, gliding rotator movement over four minutes; the treating physical therapist applied the transducer head over the superior and anterior periarticular regions of the subjects' glenohumeral joint.

- Superficial heat was administered by the use of hot packs wrapped with a towel $\left(60^{\circ} \mathrm{C}\right)$ for 10 minutes.

- Exercise for the shoulder girdle included the active and passive ROM exercises, stretching, Codman's pendulum exercises and isometric and isotonic exercises. The exercises were applied to all of the subjects by the same physical therapist. The duration of exercise was a minimum of 15 minutes and a maximum of 30 minutes. At the start of the therapy, or when a subject had severe pain, passive restricted ROM exercises and gentle stretching were used. At a later phase, or when pain lessened, exercise shifted toward active ROM exercises, and isometric and dynamic resistance exercises were added gradually, resulting in a longer duration of intervention. The duration of physical therapy intervention was 15 days (5 days each week), which is the usual treatment regimen in our department's practice. The treatment protocol was not changed during the study in order to standardize intervention for all subjects. After the study period ended, the subjects' physical therapy interventions were changed, if needed. The subjects were not allowed to take medications other than a simple analgesic (paracetamol, maximum of 500-1.000 mg daily due to their pain).

Clinical assessment, arrangement in groups and therapies were performed by three different investigators each blind to the other processes.

\section{Statistical analysis}

General characteristics of the participants are presented as mean \pm standard deviations. Comparison of scores between groups was assessed using the Mann Whitney U-test. The chisquare test was used to compare the differences in categorical variables between the groups. Differences between the visit-1, 2 and 3 scores were calculated, and then they were compared between two groups using the Mann Whitney U-test. We compared three different measurements using the Friedman repeated measurement ANOVA test. When we found significant differences among the measurements, we used Bonferroni post-hoc test for multiple comparisons. To remove the effect of age (confounding factor), analysis of covariance (ANCOVA) was used. A $p$ value $<0.05$ was considered statistically significant. The VAS rest pain score was used as the basis to calculate this study's power. The power was $97.3 \%$ based on the minimum detectable difference in means as 3.12 with a common standard deviation $=2.16$, type I error $(5 \%)$, group size $=17$.

\section{RESULTS}

The age and VAS rest pain were significantly higher in the rupture group than in the without-rupture group $(\mathrm{p}<0.001)$. Other demographic features were not significant ( $p>0.05$; see Table 1 for demographic features). When comparisons between groups were performed, the age was adjusted.

When we compared repeated measurements in each groups, visit-1 values of UCLA scale and Constant score were significantly lower than visit- 2 and visit-3 measurements ( $<<0.001$ for all comparisons); however, there was no significant difference between the visit- 2 and visit- 3 measurements ( $p>0.05$ for all comparisons) (Table 2).

The VAS rest pain, VAS motion pain, VAS sleep pain scores are shown in Table 2 . The visit-1 values 


\begin{tabular}{|c|c|c|c|c|c|c|}
\hline & \multicolumn{3}{|c|}{ Group 1} & \multicolumn{3}{|c|}{ Group 2} \\
\hline & $\mathrm{n}$ & Mean \pm SD & Range & $\mathrm{n}$ & Mean \pm SD & Range \\
\hline Age (mean in years) & & $58.3 \pm 7.3$ & $39-73$ & & $49.3 \pm 7.5$ & $47-76$ \\
\hline Pain duration (mean in months) & & $10.2 \pm 22.3$ & & & $8.8 \pm 10.2$ & \\
\hline Visual analog scale rest pain (mean score) & & $4.9 \pm 2.7$ & & & $3.0 \pm 2.6$ & \\
\hline Visual analog scale motion pain (mean score) & & $7.9 \pm 1.5$ & & & $7.0 \pm 2.2$ & \\
\hline Visual analog scale sleep pain (mean score) & & $6.5 \pm 3.4$ & & & $5.0 \pm 3.5$ & \\
\hline University of California Los Angeles score (mean score) & & $16.7 \pm 4.6$ & $9-25$ & & $18.3 \pm 3.7$ & $10-26$ \\
\hline Constant score (mean score) & & $40.7 \pm 16.3$ & $14-65$ & & $45.1 \pm 12.8$ & $12-65$ \\
\hline \multicolumn{7}{|l|}{ Gender* } \\
\hline Female & 13 & & & 18 & & \\
\hline Male & 4 & & & 8 & & \\
\hline \multicolumn{7}{|l|}{ Pathologic side ${ }^{*}$} \\
\hline Left & 6 & & & 8 & & \\
\hline Right & 11 & & & 18 & & \\
\hline
\end{tabular}

of all of the VAS scores were significantly higher than the visit- 2 and visit- 3 measurements $(p<0.001$ for all comparisons except for VAS rest value $=0.021$ ); however, there was no significant difference between the visit-2 and visit-3 VAS measurements ( $\mathrm{p}>0.05$ for all comparisons; Figure 2; Table 2).

There were no significant differences between the groups in the UCLA scale, Constant score, VAS rest pain, VAS motion pain, or VAS sleep pain scores in therapy progression $(\mathrm{p}>0.05)$ (see VAS progression in Figure 2).

No negative effects or complications appeared throughout the treatment in the patients.

\section{DISCUSSION}

Subacromial impingement syndrome and associated supraspinatus tendon ruptures are the most frequent causes of shoulder pain and functional limitation. ${ }^{[24]}$ This syndrome is generally precipitated by shoulder instability resulting from overuse and trauma leading to ROM restrictions and functional limitations with pain if untreated. ${ }^{[20]}$ Thus, effective conservative therapy programs gain importance for preventing the consequent morbidity.

In this study, there was no difference in treatment responses between the groups of patients with and without supraspinatus rupture. It can be considered that a more severe situation was normally expected in the partial rupture group because of structural defect. However only VAS in rest was statistically higher in group 1 at the beginning before treatment. The results of the physical therapy and exercise program were satisfactory in the presence of partial supraspinatus rupture. In our opinion, exercises can play a major role in this improvement. We suggest that conservative treatments are also clinically beneficial for the patients with partial supraspinatus tendon rupture. However, long-term follow-up is certainly necessary in order to reach more accurate conclusions; our recent results are preliminary and controls are still continuing for up to one year.

Table 2. Pain and functional status in both groups throughout the study period

\begin{tabular}{|c|c|c|c|c|c|c|c|c|}
\hline & \multicolumn{4}{|c|}{ Group 1 (with rupture; $\mathrm{n}=17$ ) } & \multicolumn{4}{|c|}{ Group 2 (without rupture; $n=26$ ) } \\
\hline & Visit-1 & Visit-2 & Visit-3 & $p$ & Visit-1 & Visit-2 & Visit-3 & $p$ \\
\hline VAS rest pain & $4.9 \pm 2.7$ & $1.8 \pm 1.9$ & $1.7 \pm 1.9$ & 0.001 & $3.0 \pm 2.6$ & $1.5 \pm 1.8$ & $1.3 \pm 1.8$ & 0.021 \\
\hline VAS motion pain & $7.9 \pm 1.5$ & $4.4 \pm 2.1$ & $4.4 \pm 2.1$ & 0.001 & $7.0 \pm 2.2$ & $4.5 \pm 2.4$ & $3.9 \pm 2.6$ & 0.001 \\
\hline VAS sleep pain & $6.5 \pm 3.4$ & $1.5 \pm 2.2$ & $2.0 \pm 2.5$ & 0.001 & $5.0 \pm 3.5$ & $2.1 \pm 2.9$ & $2.0 \pm 3.2$ & 0.001 \\
\hline UCLA scale & $16.7 \pm 4.6$ & $26.9 \pm 4.2$ & $26.2 \pm 4.4$ & 0.001 & $18.3 \pm 3.7$ & $27.5 \pm 5.1$ & $26.9 \pm 6.5$ & 0.001 \\
\hline Constant score & $40.7 \pm 6.3$ & $55.3 \pm 10.6$ & $54.6 \pm 8.1$ & 0.001 & $45.1 \pm 12.8$ & $59.3 \pm 10.0$ & $58.7 \pm 12.1$ & 0.001 \\
\hline
\end{tabular}




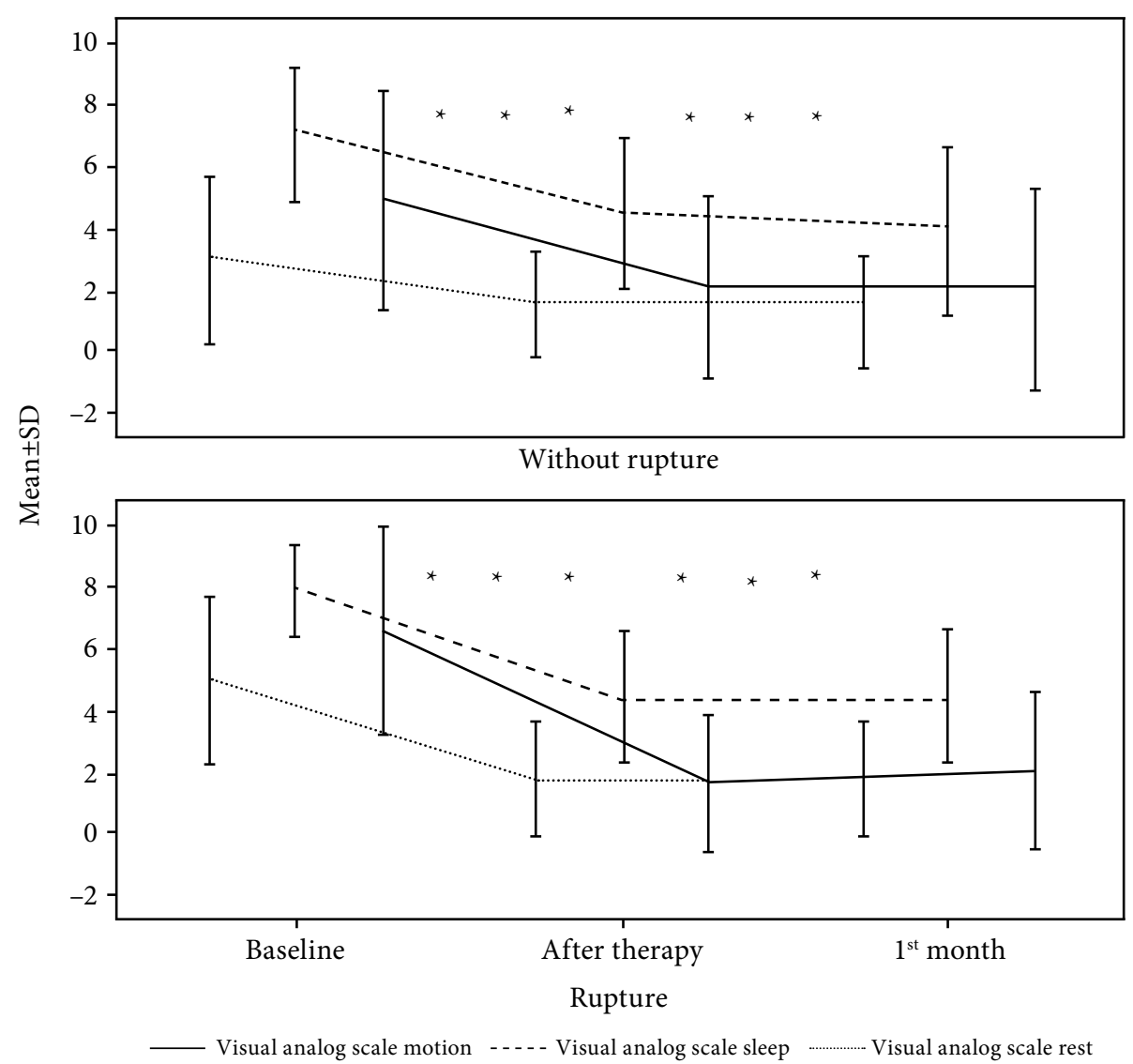

Figure 2. The changes in visual analog scale within the groups after therapy. $p>0.05$ compared with baseline.

As an element of conservative therapy, some physical therapy agents, such as ultrasound, ameliorate injured tissue via regulated circulation and induced collagen synthesis. Furthermore, physiotherapy aims to reduce pain and disability by improving the biomechanics and movement patterns of the shoulder complex. Contradictory data and opinions have been reported in reviews on painful shoulder conditions regarding the efficacy of conservative therapy interventions in chronic impingement syndromes. ${ }^{[6,25-30]}$ No sufficient evidence exists regarding ultrasound therapy in SIS. On the other hand, Kurtais et al. ${ }^{[28]}$ reported encouraging findings with US application to painful shoulders only in cases when it is combined with other physical therapy interventions. Additionally, Tascioglu et al. ${ }^{[29]}$ suggested that conservative therapy approaches, including US therapy, are beneficial in SIS patients with partial ruptures. Koubâa et al. ${ }^{[30]}$ observed improvement in shoulder pain and functions of 24 patients with full-thickness rotator cuff tears by using conservative therapy methods. Patients with SIS are often referred for physiotherapy.
Physiotherapy generally encompasses a multimodal approach to treatment. So far, little effort has been invested in establishing the effectiveness of management with physiotherapy. Few of the assessed trials favored the effectiveness of physiotherapy. Because there were many small trials with negative results, statistical pooling of the results of trials with acceptable methods would have been useful. We think that physical therapy and exercises programs contributed to the recovery period observed in both groups. Physical therapy combined with an exercise program is effective on the pain and functional level of SIS patients both with and without supraspinatus rupture in a one-month follow-up.

The duration of non-operative treatment has varied widely in the literature. ${ }^{[6,7]}$ The duration of non-operative treatment is a clinical decision that should be based on the specific set of circumstances associated with the individual patient. Although conservative therapy periods can be generally lengthened for up to several months, there are some studies reporting positive short-term efficacy. In our study, we also observed short term efficacy on pain, 
function and ROM of SIS patients both with and without ruptures.

In a retrospective study assessing the outcome of conservative treatment on 616 patients, ${ }^{[6]}$ a favorable outcome was observed for patients between 41 and 60 years old, whereas Bartolozzi et al. ${ }^{[15]}$ in another retrospective study found no difference in outcome among the different age groups. Although the mean ages of patients with ruptures were significantly different, we observed successful therapy effects in both groups without a significant difference.

Our study had some limitations. This study did not attempt to compare the results of conservative treatment with other treatment modalities. The low size of the groups and various therapy modalities previously used in many of the patients for chronic impingement syndrome also were limitations of our study. Moreover, long-term results of the study would add more value to our opinion showing the effectiveness of the conservative therapies.

In conclusion, patients with SIS who have partial rupture of supraspinatus tendon benefit from physical therapy consisting of US, TENS, superficial heat and exercise with a decrease in pain, limitation of motion, and increase in functional status in the short term. Conservative therapy should be the mainstay of treatment for patients with an irregular and thin supraspinatus tendon.

\section{Declaration of conflicting interests}

The authors declared no conflicts of interest with respect to the authorship and/or publication of this article.

\section{Funding}

The authors received no financial support for the research and/or authorship of this article.

\section{REFERENCES}

1. Neer CS 2nd. Impingement lesions. Clin Orthop Relat Res 1983;173:70-7.

2. Neer CS 2nd. Anterior acromioplasty for the chronic impingement syndrome in the shoulder: a preliminary report. J Bone Joint Surg [Am] 1972;54:41-50.

3. Chipchase LS, O'Connor DA, Costi JJ, Krishnan J. Shoulder impingement syndrome: preoperative health status. J Shoulder Elbow Surg 2000;9:12-5.

4. Bölükbasi S, Güzel VB, Simsek A, Kanatli U, Cila E. Modified and classic acromioplasty for impingement of the shoulder. Int Orthop 2002;26:10-2.
5. van der Heijden GJ, van der Windt DA, Kleijnen J, Koes BW, Bouter LM. Steroid injections for shoulder disorders: a systematic review of randomized clinical trials. Br J Gen Pract 1996;46:309-16.

6. Morrison DS, Frogameni AD, Woodworth P. Nonoperative treatment of subacromial impingement syndrome. J Bone Joint Surg [Am] 1997;79:732-7.

7. Michener LA, Walsworth MK, Burnet EN. Effectiveness of rehabilitation for patients with subacromial impingement syndrome: a systematic review. J Hand Ther 2004;17:152-64.

8. Wirth MA, Basamania C, Rockwood CA Jr. Nonoperative management of full-thickness tears of the rotator cuff. Orthop Clin North Am 1997;28:59-67.

9. Green S, Buchbinder R, Glazier R, Forbes A. Systematic review of randomised controlled trials of interventions for painful shoulder: selection criteria, outcome assessment, and efficacy. BMJ 1998;316:354-60.

10. Mantone JK, Burkhead WZ Jr, Noonan J Jr. Nonoperative treatment of rotator cuff tears. Orthop Clin North Am 2000;31:295-311.

11. Michener LA, Walsworth MK, Burnet EN. Effectiveness of rehabilitation for patients with subacromial impingement syndrome: a systematic review. J Hand Ther 2004;17:152-64.

12. Paternostro-Sluga T, Zöch C. Conservative treatment and rehabilitation of shoulder problems. Radiologe 2004;44:597-603. [Abstract]

13. Jackson BA, Schwane JA, Starcher BC. Effect of ultrasound therapy on the repair of Achilles tendon injuries in rats. Med Sci Sports Exerc 1991;23:171-6.

14. Elwakil TF. An in-vivo experimental evaluation of $\mathrm{He}-\mathrm{Ne}$ laser photostimulation in healing Achilles tendons. Lasers Med Sci 2007;22:53-9.

15. Bartolozzi A, Andreychik D, Ahmad S. Determinants of outcome in the treatment of rotator cuff disease. Clin Orthop Relat Res 1994;308:90-7.

16. Oh LS, Wolf BR, Hall MP, Levy BA, Marx RG. Indications for rotator cuff repair: a systematic review. Clin Orthop Relat Res 2007;455:52-63.

17. Zlatkin MB, Iannotti JP, Roberts MC, Esterhai JL, Dalinka MK, Kressel HY, et al. Rotator cuff tears: diagnostic performance of MR imaging. Radiology 1989;172:223-9.

18. Gartsman GM, Brinker MR, Khan M. Early effectiveness of arthroscopic repair for full-thickness tears of the rotator cuff: an outcome analysis. J Bone Joint Surg [Am] 1998;80:33-40.

19. Itoi E, Tabata S. Incomplete rotator cuff tears. Results of operative treatment. Clin Orthop Relat Res 1992; 284:128-35.

20. Constant CR, Murley AH. A clinical method of functional assessment of the shoulder. Clin Orthop Relat Res 1987;214:160-4.

21. Bankes MJ, Crossman JE, Emery RJ. A standard method of shoulder strength measurement for the Constant score with a spring balance. J Shoulder Elbow Surg 1998;7:116-21. 
22. Conboy VB, Morris RW, Kiss J, Carr AJ. An evaluation of the Constant-Murley shoulder assessment. J Bone Joint Surg [Br] 1996;78:229-32.

23. Gazielly DF, Gleyze P, Montagnon C. Functional and anatomical results after rotator cuff repair. Clin Orthop Relat Res 1994;304:43-53.

24. Hawkins RJ, Abrams JS. Impingement syndrome in the absence of rotator cuff tear (stages 1 and 2). Orthop Clin North Am 1987;18:373-82.

25. Ludewig PM, Borstad JD. Effects of a home exercise programme on shoulder pain and functional status in construction workers. Occup Environ Med 2003;60:841-9.

26. Blair B, Rokito AS, Cuomo F, Jarolem K, Zuckerman JD. Efficacy of injections of corticosteroids for subacromial impingement syndrome. J Bone Joint Surg [Am] 1996;78:1685-9.
27. Desmeules F, Côté CH, Frémont P. Therapeutic exercise and orthopedic manual therapy for impingement syndrome: a systematic review. Clin J Sport Med 2003;13:176-82.

28. Kurtaiş Gürsel Y, Ulus Y, Bilgiç A, Dinçer G, van der Heijden GJ. Adding ultrasound in the management of soft tissue disorders of the shoulder: a randomized placebocontrolled trial. Phys Ther 2004;84:336-43.

29. Taşcıoğlu F, Dalkıran İ, Öner C. Parsiyel supraspinatus tendon rüptürü olan subakromiyal sıkışma sendromlu hastalarda düşük doz lazer tedavisinin etkinliği. Türk Fiz Tip Rehab Derg 2003;49:18-22

30. Koubâa S, Ben Salah FZ, Lebib S, Miri I, Ghorbel S, Dziri C. Conservative management of full-thickness rotator cuff tears. A prospective study of 24 patients. Ann Readapt Med Phys 2006;49:62-7. [Abstract] 